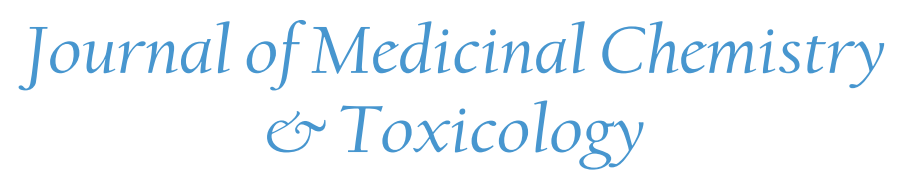

\title{
Synthesis, Docking and Evaluation of Novel Pyrazole Carboxamide Derivatives as Multifunctional Anti-Alzheimer's Agents
}

\author{
Ajmer Singh Grewal', Suneel Kumar Sharma ${ }^{1}$, Deepti Pandita ${ }^{2}$, Viney Lather ${ }^{1 *}$ \\ ${ }^{1}$ Department of Pharmaceutical Chemistry, JCDM College of Pharmacy, Sirsa, 125055, Haryana, India \\ ${ }^{2}$ Department of Pharmaceutics, JCDM College of Pharmacy, Sirsa, 125055, Haryana, India
}

*Corresponding authors: Viney Lather, Department of Pharmaceutical Chemistry, JCDM College of Pharmacy, Sirsa-125055, Haryana, India; Tel: +91-1666-238114; E-mail: vinnylather@gmail.com

\begin{abstract}
Alzheimer's disease (AD) is a major public health problem. The dual inhibitors of monoamine oxidase-B (MAO-B) and acetyl cholinesterase (AchE) are reported as effective in treatment of $\mathrm{AD}$. The present research work was planned to design, synthesize and evaluate pyrazole carboxamide derivatives as multifunctional agents for treatment of $\mathrm{AD}$. A series of substituted pyrazole derivatives were synthesized by refluxing chalcone derivatives with substituted semicarbazides and evaluated by in silico docking studies to determine the binding interactions for the best fit conformations in the binding site of MAO-B protein. The selected compounds from the in silico studies were evaluated further for their cognition enhancing and AchE inhibitory activity. Compounds 8 and 11 significantly reversed the scopolamine induced amnesia on elevated plus maze (EPM) model and compound 8 was found to be most potent. The selected compounds also significantly reduced AchE activity in brain. These newly designed molecules could act as starting hits for the development of effective and potent multifunctional agents for the potential treatment of AD.
\end{abstract}

Received Date: February 13, 2017

Accepted Date: February 27, 2017

Published Date: March 22, 2017

Citation: Lather V., et al. Synthesis, Docking and Evaluation of Novel Pyrazole Carboxamide Derivatives as Multifunctional Anti-Alzheimer's Agents. (2017) J Med Chem Toxicol 2(1): 47-54.

DOI: $10.15436 / 2575-808 X .17 .1356$

Keywords: Acetyl cholinesterase inhibitors; Alzheimer; Anti-Alzheimer's activity; MAO-B inhibitors; Pyrazoles

\section{Introduction}

Alzheimer's disease (AD), the most common form of dementia in elderly people, is a complex age-dependent neurodegenerative disorder of the central nervous system, characterized by progressive impairment in memory, cognitive functions, and behavioral disturbances ${ }^{[1]}$. The incidence of AD is increasing dramatically worldwide, largely due to amnesia. Various molecular studies suggest that AD has multiple etiologies, including genetic mutations, susceptible genes and environmental factors that promote formation and accumulation of insoluble amyloid- $\beta$ and hyper-phosphorylated tau ${ }^{[2]}$. Patients with AD have a deficiency of cholinergic neurons in the central nervous system. Acetylcholinesterase (AChE) controls acetylcholine to proper levels by degradation; accordingly, excessive AChE activity leads to constant acetylcholine deficiency, memory, and cognitive impairments. This observation led to the development of AChE inhibitors as possible therapy for the loss of cogni-

tive function ${ }^{[3,4]}$. Another potential therapy for AD is the use of monoamine oxidase-B (MAO-B) inhibitors, as MAO-B type activity is increased in patients with $\mathrm{AD}^{[5]}$. There are different recognized mechanisms by which MAO-B inhibitors could prevent neurodegeneration. First, they may decrease the free radical formation, which cause membrane and DNA destruction, from normal metabolism of the biogenic amines by inhibition of MAO-B in the central nervous systems. Second, they exhibit protective effects against neuronal apoptosis in cell culture. Third, MAO-B inhibitors were shown to reduce the secretion of neurotoxic products ${ }^{[6-8]}$. The MAO-B inhibitory properties of 1,3,5-triphenyl-2-pyrazoline derivatives had been reported ear$\operatorname{lier}^{[9-11]}$. These findings urged the scientists to synthesize various pyrazole derivatives as MAO-B inhibitors and a significant number of pyrazole derivatives were found to have MAO-B inhibitory activity comparable to or higher than the reference

Copyrights: (C) 2017 Lather V. This is an Open access article distributed under the terms of Creative Commons Attribution 4.0 International License. 
compounds. Some of the reported pyrazole derivatives were also found to inhibit the $\mathrm{AChE}^{[12-15]}$. Considering the facts that pyrazole derivatives are promising compounds for dual MAO-B and $\mathrm{AChE}$ inhibition, this research work has been planned to synthesize and evaluate some novel pyrazole carboxamide derivatives as multifunctional anti-AD agents.

\section{Materials and Methods}

All the chemicals were purchased from Spectrochem Ltd., Otto Chemie Pvt. Ltd., Molychem, Sigma Aldrich, etc. and were used as such for the experiments. Melting points were determined using Veego VMP-D melting point apparatus. ${ }^{1} \mathrm{H}-\mathrm{NMR}$ spectra were recorded by Bruker Avance II $300 \mathrm{MHz}$ NMR spectrometer using DMSO- $\mathrm{d}_{6}$ as solvent and are expressed in parts per million $(\delta, \mathrm{ppm})$ downfield from tetramethylsilane (internal standard). Infrared (IR) spectra were recorded by $\mathrm{KBr}$ disc method on a Shimadzu IR affinity FTIR spectrophotometer.

\section{Synthesis of pyrazole derivatives}

The chalcone derivatives were prepared by condensing 4-subsituted acetophenones $(0.01 \mathrm{~mol})$ with furfural $(0.01 \mathrm{~mol})$ in methanol using $10 \%$ sodium hydroxide $(10 \mathrm{ml})$ and stirred at 20 - $25{ }^{\circ} \mathrm{C}$ temperature maintained using ice water bath. The reaction mixture was kept at room temperature for $24 \mathrm{hrs}$ followed by addition to ice cold water and acidification with hydrochloric acid. The precipitates were filtered and washed with cold water. The substituted semicarbazides were obtained by addition of a solution of isocyanates $(0.05 \mathrm{~mol})$ in benzene $(65 \mathrm{ml})$ drop wise in small portions with cooling using ice and vigorous stirring to a solution of hydrazine hydrate $(0.05 \mathrm{~mol})$ in methanol $(100$ $\mathrm{ml}$ ). After the reaction was concluded, the hydrazine-N, N'-dicarbomethylamide (side product) was removed by cold filtration and substituted semicarbazides were collected. A solution of sodium hydroxide $(0.025 \mathrm{~mol})$ in $5 \mathrm{ml}$ of water was added to a solution of chalcone derivatives $(0.01 \mathrm{~mol})$ and substituted semicarbazides $(0.012 \mathrm{~mol})$ in $25 \mathrm{ml}$ of ethanol followed by refluxing for $8 \mathrm{hrs}$. The reaction products were poured into crushed ice and precipitates which separated out were filtered, dried and recrystallized from ethanol. The products were monitored by TLC on silica gel G Plates.

5-(furan-2-yl)-3-(4-methylphenyl)-N-phenyl-4,5-dihydro-1Hpyrazole-1-carboxamide (1): $\mathrm{IR}\left(\mathrm{KBr}\right.$ Pellets) $v \mathrm{~cm}^{-1}: 1670(\mathrm{C}=\mathrm{O}$ str., amide), 3296 (N-H str., amide), 1597 (N-H bend, amide), 1238 (C=N str.), 1604 ( $\mathrm{C}=\mathrm{C}$ str., aromatic), 2856 (C-H str., aliphatic), 2980 (C-H str., aromatic); ${ }^{1} \mathrm{H}-\mathrm{NMR}\left(\delta \mathrm{ppm}, \mathrm{DMSO}-\mathrm{d}_{6}\right)$ : $1.18\left(\mathrm{t}, 1 \mathrm{H}, \mathrm{CH}_{3}\right), 2.32-2.34(\mathrm{~m}, 1 \mathrm{H}$ of pyrazoline $), 6.41(\mathrm{dd}, 1 \mathrm{H}$, $\mathrm{CH}$ of $\mathrm{C}_{3}, \mathrm{C}_{4}$ and $\mathrm{C}_{5}$ of furan-2yl, $\left.\mathrm{J}=2.5,4.5 \mathrm{~Hz}\right), 6.54-6.56(\mathrm{~m}$, $2 \mathrm{H}, \mathrm{CH}$ of $\mathrm{C}_{3}$ and $\mathrm{C}_{6}$ of $\left.\mathrm{C}_{6} \mathrm{H}_{4} \mathrm{OC}_{2} \mathrm{H}_{5}\right), 6.73-6.76(\mathrm{~m}, 1 \mathrm{H}, 5 \mathrm{CH}$ of $\left.\mathrm{C}_{6} \mathrm{H}_{5}\right), 7.03\left(\mathrm{dd}, 1 \mathrm{H}, \mathrm{CH}\right.$ of $\mathrm{C}_{2}$ and $\mathrm{C}_{6}$ of $\left.\mathrm{C}_{6} \mathrm{H}_{4} \mathrm{OC}_{2} \mathrm{H}_{5}\right)$.

5-(furan-2-yl)-3-(4-methoxyphenyl)-N-phenyl-4,5-dihydro1H-pyrazole-1-carboxamide (2): IR (KBr Pellets) $v \mathrm{~cm}^{-1}: 1114$ (C-O str., ether), 1668 ( $\mathrm{C}=\mathrm{O}$ str., amide), 3298 (N-H str., amide), $1240(\mathrm{C}=\mathrm{N}$ str., pyrazoline), 1602 ( $\mathrm{C}=\mathrm{C}$ str., aromatic), 3124 (C-H str., aromatic), 1082 (C=O str., ether), 2842 (C-H str., alkane).
5-(furan-2-yl)-3-(4-ethoxylphenyl)-N-phenyl-4,5-dihydro-1Hpyrazole-1-carboxamide (3): IR (KBr Pellets) $v \mathrm{~cm}^{-1}: 1114(\mathrm{C}-\mathrm{O}$ str., ether), 1666 ( $\mathrm{C}=\mathrm{O}$ str., amide), 3396 ( $\mathrm{C}=\mathrm{O}$ str., amide ), 2980 (C-H str., alkane), 1438 (C-H bend, alkane) 1516 (C=C str., aromatic), 2927 (C-H str., aromatic), 1039 (N-N str., pyrazoline), 1334 (C-N str., pyrazoline); ${ }^{1} \mathrm{H}-\mathrm{NMR}(\delta$ ppm, DMSO-d $): 1.21$ $\left(\mathrm{t}, 1 \mathrm{H}, \mathrm{CH}_{3}\right.$ of $\left.\mathrm{OC}_{2} \mathrm{H}_{5}\right), 3.33-3.36(\mathrm{~m}, 1 \mathrm{H}$ of pyrazoline $), 4.08$ (q, $2 \mathrm{H}, \mathrm{CH}_{2}$ of $\left.\mathrm{OC}_{2} \mathrm{H}_{5}\right), 6.30\left(\mathrm{dd}, 1 \mathrm{H}, \mathrm{CH}\right.$ of $\mathrm{C}_{3}, \mathrm{C}_{4}$ and $\mathrm{C}_{5}$ offuran-2yl), $7.24-7.30\left(\mathrm{~m}, 2 \mathrm{H}, \mathrm{CH}\right.$ of $\mathrm{C}_{3}$ and $\mathrm{C}_{6}$ of $\left.\mathrm{C}_{6} \mathrm{H}_{4} \mathrm{OC}_{2} \mathrm{H}_{5}\right)$, $7.25\left(\mathrm{~s}, 1 \mathrm{H}, \mathrm{CH}\right.$ of $\mathrm{C}_{4}$ of $\left.\mathrm{C}_{6} \mathrm{H}_{5}\right), 7.28\left(\mathrm{~m}, 2 \mathrm{H}, \mathrm{CH}\right.$ of $\mathrm{C}_{3}$ and $\mathrm{C}_{5}$ of $\left.\mathrm{C}_{6} \mathrm{H}_{5}\right), 8.02(\mathrm{~s}, 1 \mathrm{H}, \mathrm{NH}$ of $\mathrm{NH}-\mathrm{C}=\mathrm{O})$.

5-(furan-2-yl)-3-(4-chlorophenyl)-N-phenyl-4,5-dihydro1H-pyrazole-1-carboxamide(4): IR (KBr Pellets) $v \mathrm{~cm}^{-1}: 1674$ ( $\mathrm{C}=\mathrm{O}$ str., amide), 1597 (N-H bend, amide), 3296 (N-H str., amide), 1238 ( $\mathrm{C}=\mathrm{N}$ str., Pyrazoline), 1674 ( $\mathrm{C}=\mathrm{C}$ str., aromatic), 2926 (C-H str., aromatic), 879 (C-Cl str.), 1083 (N=N str., Pyrazoline).

5-(furan-2-yl)-3-(4-bromophenyl)-N-phenyl-4,5-dihydro-1Hpyrazole-1-carboxamide (5): IR (KBr Pellets) $v \mathrm{~cm}^{-1}: 1670$ ( $\mathrm{C}=\mathrm{O}$ str., amide), 3296 (N-H str., amide), $1238(\mathrm{C}=\mathrm{N}$ str. $)$, 1604 (C=C str., alkene), 2856 (C-H str., alkane), 609 (C-Br str.); ${ }^{1} \mathrm{H}-\mathrm{NMR}\left(\delta \mathrm{ppm}, \mathrm{DMSO}-\mathrm{d}_{6}\right): 3.49$ - 3.51 (m, 1H of Pyrazoline), $6.42\left(\mathrm{dd}, 1 \mathrm{H}, \mathrm{CH}\right.$ of $\mathrm{C}_{3}, \mathrm{C}_{4}$ and $\mathrm{C}_{5}$ offuran-2yl, $\left.\mathrm{J}=2.5,4.5 \mathrm{~Hz}\right)$, $7.55-7.57\left(\mathrm{~m}, 2 \mathrm{H}, \mathrm{CH}\right.$ of $\mathrm{C}_{3}$ and $\mathrm{C}_{6}$ of $\left.\mathrm{C}_{6} \mathrm{H}_{4} \mathrm{OC}_{2} \mathrm{H}_{5}\right), 7.62(\mathrm{~s}$, $1 \mathrm{H}, \mathrm{CH}$ of $\mathrm{C}_{4}$ of $\left.\mathrm{C}_{6} \mathrm{H}_{5}\right), 7.64\left(\mathrm{~m}, 2 \mathrm{H}, \mathrm{CH}\right.$ of $\mathrm{C}_{3}$ and $\mathrm{C}_{5}$ of $\left.\mathrm{C}_{6} \mathrm{H}_{5}\right)$, $7.66-7.83\left(\mathrm{~m}, 1 \mathrm{H}, \mathrm{CH}\right.$ of $\mathrm{C}_{2}$ and $\mathrm{C}_{6}$ of $\left.\mathrm{C}_{6} \mathrm{H}_{5}\right), 7.85(\mathrm{dd}, 1 \mathrm{H}, \mathrm{CH}$ of $\mathrm{C}_{2}$ and $\mathrm{C}_{6}$ of $\left.\mathrm{C}_{6} \mathrm{H}_{4} \mathrm{OC}_{2} \mathrm{H}_{5}, \mathrm{~J}=8.8,4.5 \mathrm{~Hz}\right), 8.03(\mathrm{~s}, 1 \mathrm{H}, \mathrm{NH}$ of $\mathrm{NH}-\mathrm{C}=\mathrm{O})$.

5-(furan-2-yl)-3-(4-flourophenyl)- $\mathrm{N}$-phenyl-4,5-dihydro-1Hpyrazole-1-carboxamide (6): IR (KBr Pellets) $v \mathrm{~cm}^{-1}: 1674$ ( $\mathrm{C}=\mathrm{O}$ str., amide), 3296 (N-H str., amide), 1236 (C=N str., Pyrazoline), 1238 ( $\mathrm{C}=\mathrm{N}$ str., Pyrazoline), 1660 ( $\mathrm{C}=\mathrm{C}$ str., aromatic), 2856 (C-H str., aromatic), 1172 (C-F str.).

5-(furan-2-yl)-3-(4-nitrophenyl)-N-phenyl-4,5-dihydro-1Hpyrazole-1-carboxamide(7): IR (KBr Pellets) $v \mathrm{~cm}^{-1}: 1670$ ( $\mathrm{C}=\mathrm{O}$ str., amide), 3296 (N-H str., amide), 1236 (C=N str., Pyrazoline), 1545 (N-O str., nitro), 1334 (N-O str., nitro), 1670 (C=C, aromatic), 2924 (C-H, str., aromatic).

\section{5-(furan-2-yl)-3-(4-methylphenyl)-N-(propan-2-yl)-4,5-dihy-} dro-1H-pyrazole-1-carboxamide(8): IR (KBr Pellets) $v \mathrm{~cm}^{-1}$ : 1670 (C=O str., amide), 3124 (N-H str., amide), 1257 ( $\mathrm{C}=\mathrm{N}$ str.), 1600 (C=C str., aromatic), 3030 (C-H str., aromatic), 2866 (C-H str., alkane); ${ }^{1} \mathrm{H}-\mathrm{NMR}(\delta$ ppm, DMSO-d $)$ : $1.31\left(\mathrm{t}, 1 \mathrm{H}, \mathrm{CH}_{3}\right)$, 3.37 - 3.38 (m, 1H of Pyrazoline), $4.02(\mathrm{q}, 1 \mathrm{H}, \mathrm{j}=7.0 \mathrm{~Hz}), 6.30$ (dd, $1 \mathrm{H}, \mathrm{CH}$ of $\mathrm{C}_{3}, \mathrm{C}_{4}$ and $\mathrm{C}_{5}$ offuran-2yl), $7.20-7.22(\mathrm{~m}, 2 \mathrm{H}$, $\mathrm{CH}$ of $\mathrm{C}_{3}$ and $\mathrm{C}_{6}$ of $\left.\mathrm{C}_{6} \mathrm{H}_{4} \mathrm{OC}_{2} \mathrm{H}_{5}\right), 7.88(\mathrm{~s}, 1 \mathrm{H}, \mathrm{NH}$ of $\mathrm{NH}-\mathrm{C}=\mathrm{O})$.

5-(furan-2-yl)-3-(4-methoxyphenyl)-N-(propan-2-yl)-4,5-dihydro-1H-pyrazole-1-carboxamide (9): IR (KBr Pellets) $v \mathrm{~cm}^{-}$ ${ }^{1}$ : 1674 (C=O str., amide), 3122 (N-H str., amide), $1230(\mathrm{C}=\mathrm{N}$ str.), 1631 (C=C str., aromatic), 3080 (C-H str., aromatic), 2862 (C-H str., alkane), 1157 (C-O str., ether); ${ }^{1} \mathrm{H}-\mathrm{NMR}$ ( $\delta$ ppm, DM$\left.\mathrm{SO}-\mathrm{d}_{6}\right): 1.31(\mathrm{t}, 1 \mathrm{H}, \mathrm{CH} 3), 3.38-3.39$ (m, 1H of pyrazoline), $6.92\left(\mathrm{dd}, 1 \mathrm{H}, \mathrm{CH}\right.$ of $\mathrm{C}_{3}, \mathrm{C}_{4}$ and $\mathrm{C}_{5}$ offuran-2yl, $\left.\mathrm{J}=2.5,4.5 \mathrm{~Hz}\right)$, 7.04 - $7.06\left(\mathrm{~m}, 2 \mathrm{H}, \mathrm{CH}\right.$ of $\mathrm{C}_{3}$ and $\mathrm{C}_{6}$ of $\left.\mathrm{C}_{6} \mathrm{H}_{4} \mathrm{OC}_{2} \mathrm{H}_{5}\right), 7.88$ (dd, 
$1 \mathrm{H}, \mathrm{CH}$ of $\mathrm{C}_{2}$ and $\mathrm{C}_{6}$ of $\left.\mathrm{C}_{6} \mathrm{H}_{4} \mathrm{OC}_{2} \mathrm{H}_{5}, \mathrm{~J}=8.8,4.5 \mathrm{~Hz}\right), 8.0(\mathrm{~s}, 1 \mathrm{H}$, $\mathrm{NH}$ of $\mathrm{NH}-\mathrm{C}=\mathrm{O}$ ).

5-(furan-2-yl)-3-(4-ethoxyphenyl)-N-(propan-2-yl)-4,5-dihydro-1H-pyrazole-1-carboxamide (10): $\mathrm{IR}$ (KBr Pellets) $v \mathrm{~cm}^{-1}$. 1668 ( $\mathrm{C}=\mathrm{O}$ str., amide), 3122 (N-H str., amide), 1249 ( $\mathrm{C}=\mathrm{N}$ str.), $1668\left(\mathrm{C}=\mathrm{C}\right.$ str., aromatic), 2858 (C-H str., alkane); ${ }^{1} \mathrm{H}-\mathrm{NMR}(\delta$ ppm, DMSO-d $\left.)_{6}\right): 1.19\left(\mathrm{t}, 1 \mathrm{H}, \mathrm{CH}_{3}\right.$ of $\left.\mathrm{OC}_{2} \mathrm{H}_{5}\right), 1.21-1.22(\mathrm{~m}$, $1 \mathrm{H}$, propan-2-yl), $4.01-4.04$ (m, 1H of pyrazoline), 4.06 (q, 2H, $\mathrm{CH}_{2}$ of $\left.\mathrm{OC}_{2} \mathrm{H}_{5}, \mathrm{~J}=7.0 \mathrm{~Hz}\right), 6.30\left(\mathrm{dd}, 1 \mathrm{H}, \mathrm{CH}\right.$ of $\mathrm{C}_{3}, \mathrm{C}_{4}$ and $\mathrm{C}_{5}$ of furan-2yl), $6.93-6.95\left(\mathrm{~m}, 2 \mathrm{H}, \mathrm{CH}\right.$ of $\mathrm{C}_{3}$ and $\mathrm{C}_{6}$ of $\left.\mathrm{C}_{6} \mathrm{H}_{4} \mathrm{OC}_{2} \mathrm{H}_{5}\right)$, $7.56\left(\mathrm{dd}, 1 \mathrm{H}, \mathrm{CH}\right.$ of $\mathrm{C}_{2}$ and $\mathrm{C}_{6}$ of $\left.\mathrm{C}_{6} \mathrm{H}_{4} \mathrm{OC}_{2} \mathrm{H}_{5}\right), 8.12(\mathrm{~s}, 1 \mathrm{H}, \mathrm{NH}$ of $\mathrm{NH}-\mathrm{C}=\mathrm{O})$.

5-(furan-2-yl)-3-(4-chlorophenyl)-N-(propan-2-yl)-4,5-dihydro-1H-pyrazole-1-carboxamide (11): IR (KBr Pellets) $v \mathrm{~cm}^{-1}$ : $1666(\mathrm{C}=\mathrm{O}$ str., amide), 3126 (N-H str., amide), $1226(\mathrm{C}=\mathrm{N}$ str., pyrazoline), 1666 ( $\mathrm{C}=\mathrm{C}$ str., aromatic), 2926 (C-H str., aromatic), 3080 (C-H str., alkane), 740 (C-Cl str.).

5-(furan-2-yl)-3-(4-fluorophenyl)-N-(propan-2-yl)-4,5-dihydro-1H-pyrazole-1-carboxamide(12): $\mathrm{IR}$ (KBr Pellets) $v \mathrm{~cm}^{-1}$ : 1674 (C=O str., amide), 3246 (N-H str., amide), $1226(\mathrm{C}=\mathrm{N}$ str., pyrazoline), 1593 ( $\mathrm{C}=\mathrm{C}$ str., aromatic), 2860 (C-H str., aromatic), 3128 (C-H str., alkane), 1458 (C-H bend, alkane), 1168 (C-F str.).

5-(furan-2-yl)-3-(4-nitrophenyl)-N-(propan-2-yl)-4,5-dihydro1H-pyrazole-1-carboxamide (13): IR (KBr Pellets) $v \mathrm{~cm}^{-1}: 1600$ $(\mathrm{C}=\mathrm{O}$ str., amide), 3290 (N-H str., amide), 1598 (C=C str., aromatic), 2854 (C-H str., aromatic), 3124 (C-H str., alkane), 1456 (-C-H bend, alkane), 1598 (N-O str., nitro), 1340 (N-O str., nitro).

5-(furan-2-yl)-3-(4-bromophenyl)-N-(propan-2-yl)-4,5-dihydro-1H-pyrazole-1-carboxamide (14): $\mathrm{IR}$ (KBr Pellets) $v \mathrm{~cm}^{-1}$ : 1674 ( $\mathrm{C}=\mathrm{O}$ str., amide), 3392 (N-H str., amide), 1284 (C=N str.), 1589 (C=C str., aromatic), 2862 (C-H str., aromatic), 2968 (C-H str., alkane), 1477 (-C-H bend, alkane), 551 (C-Br str.).

5-(furan-2-yl)-3-(4-methylphenyl)-N-benzyl-4,5-dihydro-1Hpyrazole-1-carboxamide (15): $\mathrm{IR}$ ( $\mathrm{KBr}$ Pellets) $v \mathrm{~cm}^{-1}: 1645$ ( $\mathrm{C}=\mathrm{O}$ str., amide), 3288 (N-H str., amide), 1589 ( $\mathrm{N}-\mathrm{H}$ bend, amide), 1298 ( $\mathrm{C}=\mathrm{N}$ str.), 1573 ( $\mathrm{C}=\mathrm{C}$ str., aromatic), 2927 (C-H str., aromatic); ${ }^{1} \mathrm{H}-\mathrm{NMR}\left(\delta \mathrm{ppm}, \mathrm{DMSO}-\mathrm{d}_{6}\right): 1.25\left(\mathrm{t}, 1 \mathrm{H}, \mathrm{CH}_{3}\right), 2.34$ $-2.36\left(\mathrm{~m}, 1 \mathrm{H}\right.$ of pyrazoline), $3.38\left(\mathrm{~s}, 2 \mathrm{H}, \mathrm{CH}_{2}\right.$ of $\left.\mathrm{C}_{6} \mathrm{H}_{5}\right), 6.24(\mathrm{dd}$, $1 \mathrm{H}, \mathrm{CH}$ of $\mathrm{C}_{3}, \mathrm{C}_{4}$ and $\mathrm{C}_{5}$ of furan-2yl), $7.26-7.28(\mathrm{~m}, 2 \mathrm{H}, \mathrm{CH}$ of $\mathrm{C}_{3}$ and $\mathrm{C}_{6}$ of $\left.\mathrm{C}_{6} \mathrm{H}_{4} \mathrm{OC}_{2} \mathrm{H}_{5}\right), 7.35\left(\mathrm{~s}, 1 \mathrm{H}, \mathrm{CH}\right.$ of $\mathrm{C}_{4}$ of $\left.\mathrm{C}_{6} \mathrm{H}_{5}\right), 7.38$ $\left(\mathrm{m}, 2 \mathrm{H}, \mathrm{CH}\right.$ of $\mathrm{C}_{3}$ and $\mathrm{C}_{5}$ of $\left.\mathrm{C}_{6} \mathrm{H}_{5}\right), 7.50-7.52\left(\mathrm{~m}, 1 \mathrm{H}, \mathrm{CH}\right.$ of $\mathrm{C}_{2}$ and $\mathrm{C}_{6}$ of $\left.\mathrm{C}_{6} \mathrm{H}_{5}\right), 7.88$ (dd, $1 \mathrm{H}, \mathrm{CH}$ of $\mathrm{C}_{2}$ and $\mathrm{C}_{6}$ of $\mathrm{C}_{6} \mathrm{H}_{4} \mathrm{OC}_{2} \mathrm{H}_{5}$ ), $7.93(\mathrm{~s}, 1 \mathrm{H}, \mathrm{NH}$ of $\mathrm{NH}-\mathrm{C}=\mathrm{O})$.

5-(furan-2-yl)-3-(4-methoxyphenyl)-N-benzyl-4,5-dihydro1H-pyrazole-1-carboxamide (16): IR (KBr Pellets) $v \mathrm{~cm}^{-1}: 1693$ ( $\mathrm{C}=\mathrm{O}$ str., amide), 3280 (N-H str., amide), 1573 (N-H bend, amide), $1296(\mathrm{C}=\mathrm{N}$ str., pyrazoline $), 1573(\mathrm{C}=\mathrm{C}$ str., aromatic $)$, 2926 (C-H str., aromatic), 3192 (C-H str., alkane), 1076 (C-O str., ether).
5-(furan-2-yl)-3-(4-ethoxyphenyl)-N-benzyl-4,5-dihydro-1Hpyrazole-1-carboxamide (17): IR (KBr Pellets) $v \mathrm{~cm}^{-1}: 1631$ ( $\mathrm{C}=\mathrm{O}$ str., amide), 3288 ( $\mathrm{N}-\mathrm{H}$ str., amide), 1577 ( $\mathrm{N}-\mathrm{H}$ bend, amide), 1296 ( $\mathrm{C}=\mathrm{N}$ str., pyrazoline), 1577 ( $\mathrm{C}=\mathrm{C}$ str., aromatic), 2929 (C-H str., aromatic), 3084 (C-H str., alkane), 1111 (C-O str., ether).

5-(furan-2-yl)-3-(4-chlorophenyl)-N-benzyl-4,5-dihydro-1Hpyrazole-1-carboxamide (18): $\mathrm{IR}$ ( $\mathrm{KBr}$ Pellets) $v \mathrm{~cm}^{-1}: 1666$ (C=O str., amide), 3290 (N-H str., amide), 1298 (C=N str.), 1571 (C=C str., aromatic), 2927 (C-H str., aromatic), 696 (C-Cl str.).

5-(furan-2-yl)-3-(4-bromophenyl)-N-benzyl-4,5-dihydro-1Hpyrazole-1-carboxamide (19): $\mathrm{IR}$ (KBr Pellets) $v \mathrm{~cm}^{-1}: 1641$ ( $\mathrm{C}=\mathrm{O}$ str., amide), 3286 ( $\mathrm{N}-\mathrm{H}$ str., amide), $1570(\mathrm{~N}-\mathrm{H}$ bend, amide), 1301 ( $\mathrm{C}=\mathrm{N}$ str., pyrazoline), $1570(\mathrm{C}=\mathrm{C}$ str., aromatic), 2927 (C-H str., aromatic), 3086 (C-H str., alkane), 586 (C-Br str.).

5-(furan-2-yl)-3-(4-nitrophenyl)-N-benzyl-4,5-dihydro-1Hpyrazole-1-carboxamide (20): IR ( $\mathrm{KBr}$ Pellets) $v \mathrm{~cm}^{-1}: 1660$ ( $\mathrm{C}=\mathrm{O}$ str., amide), 3288 (N-H str., amide), 1573 (N-H bend, amide), 1298 ( $\mathrm{C}=\mathrm{N}$ str.), 1573 ( $\mathrm{C}=\mathrm{C}$ str., aromatic), 2927 (C-H str., aromatic), 3086 (C-H str., alkane), 1367 (N-O str., nitro), 1573 (N-O str., nitro).

5-(furan-2-yl)-3-(4-fluorophenyl)-N-benzyl-4,5-dihydro-1Hpyrazole-1-carboxamide (21): IR (KBr Pellets) $v \mathrm{~cm}^{-1}: 1651$ ( $\mathrm{C}=\mathrm{O}$ str., amide), 3290 ( $\mathrm{N}-\mathrm{H}$ str., amide), 1575 (N-H bend, amide), 1296 ( $\mathrm{C}=\mathrm{N}$ str., pyrazoline), $1575(\mathrm{C}=\mathrm{C}$ str., aromatic), 2926 (C-H str., aromatic), 1083 (C-F str.).

\section{Molecular docking studies}

Docking was carried out for the synthesized molecules in the binding site of MAO-B protein (PDB entry: 2V61) and AChE protein (PDB entry: 1EVE) using AutoDock Vina ${ }^{[16]}$ and graphical user interface, AutoDock tools (ADT) installed on windows $7^{[17]}$. The geometries of the ligands were optimized by Open Babel using molecular mechanics force field ${ }^{[18]}$. The ligands were prepared for docking by using ADT by assigning the charges to all the atoms and storing them as PDBQT file. The PDB files of MAO-B and AChE was edited with the help of PyMOL, and $\alpha$ chain was removed along with the complexed inhibitor. All water molecules and interacting ions were removed (The PyMOL Molecular Graphics System, Version 1.7.4 Schrödinger, LLC). The PDBQT file for the protein was generated with the help of ADT by addition of all polar hydrogen atoms followed by charge assignment to the macromolecule. The calculations of grid parameters were accomplished by the Grid tool in ADT. The grid parameter file possessing all the information about the size of grid, protein, ligand and geometry of search space was prepared and saved as 'Conf.txt'. Accuracy of the docking protocol was determined by docking co-crystallized MAO-B ligand; 7-(3-chlorobenzyloxy)-4-(methylamino) methyl-coumarin into the active site of MAO-B and AChE ligand donepezil in the active site of AChE. The optimized ligand molecules in PDBQT format were docked in the active site of MAO-B and AChE with Auto Dock Vina. Docking runs were launched from the command line, followed by the generation and scoring of best nine poses, for each and every ligand using the scoring function. At 
the end of the docking, ligands with most favorable free energy of binding were selected. The protein-ligand interactions were further analyzed for the docked ligands by using PyMOL and best poses in the binding site were drawn.

\section{Biological evaluation}

Animals: Swiss male albino rats (25 - 30 g) were purchased from Animal House of Lala Lajpat Rai University of Veterinary and Animal Sciences, Hisar (India). Animals were housed in an alternating light and dark cycle of $12 \mathrm{hrs}$ each. All the rats were feeded with commercially available rat's normal pellet diet and water ad libitum. The experimental protocol was approved by Institutional Animals Ethics Committee and Committee for the Purpose of Control and Supervision of Experiments on Animals (Approval No. JCDMCOP/IAEC/07/15/26).

Evaluation of antiamnesic and cognition enhancing activity: Animals were divided into 8 groups with 6 animals in each group. The mice were pre-treated orally for 7 days with selected synthesized molecules $(10 \mathrm{mg} / \mathrm{kg})$ suspended in $0.5 \% \mathrm{CMC}$. Donepezil $(5 \mathrm{mg} / \mathrm{kg})$ and scopolamine $(0.4 \mathrm{mg} / \mathrm{kg})$ were dissolved in water for injection before administration. Scopolamine was administered $1 \mathrm{hr}$ after the test drug and $30 \mathrm{~min}$ after donepezil administration. The control group was treated with vehicle $(0.5 \% \mathrm{CMC}$ suspension) only. EPM test was performed for the evaluation of antiamnesic and cognition enhancing activity by measuring TL. The fabricated plus maze used in the study, consisted of two opposite open arms, crossed with two enclosed arms of same dimensions. The arms were connected with a central square to give the apparatus a plus sign appearance. The maze was kept in dim light room at an elevated height on $7^{\text {th }}$ day, $1 \mathrm{hr}$ after the last dose of selected molecules, pre-treatment and 30 min after donepezil treatment, individual rats from each group were placed on the end of one of the open arms facing away from the centre. Time taken by the animal to enter one of the closed arms (TL considered as day 1) was recorded with the help of a stop watch. The rats were left in the enclosed arm for $10-15 \mathrm{~s}$ and returned to its home cage. On day 2 , the same procedure was repeated and TL was recorded ${ }^{[3,19]}$.

Evaluation of AChE inhibitory activity: For determination of AChE inhibitory activity of the selected molecules, rats were distributed into 6 groups ( 1 control +5 test compounds) with each having 6 rats. The control group received vehicle only. The rats were pretreated orally once with the selected molecules $(10 \mathrm{mg} /$ $\mathrm{kg}$ ) for 7 days and on day 7, $1 \mathrm{hr}$ after the last dose all rats were quickly killed using light ether anesthesia and brain was isolated from the skull immediately. Brain was homogenized in ice cold $0.1 \mathrm{M}$ phosphate buffer ( $\mathrm{pH} \mathrm{8.0)}$ ), centrifuged for $10 \mathrm{~min}$ at $4{ }^{\circ} \mathrm{C}$, and supernatant was mixed with phosphate buffer $(\mathrm{pH}$ 7.0) followed by addition of substrate acetyl thiocholine iodide and dithiobisnitrobenzoic acid reagent. Change in absorbance per minute of the sample was read at $412 \mathrm{~nm}$ using a spectrophotometer. The enzyme activity was expressed as the moles of substrate hydrolyzed $/ \mathrm{min} / \mathrm{mg}$ of $\operatorname{protein}^{[3]}$.

\section{Results and Discussion}

\section{Chemistry}

The synthesis of designed pyrazole carboxamide derivatives was carried out as demonstrated in Figure 1. Chalcones were obtained by reacting furfural with 4-substituted acetophenone derivatives in ice bath followed by refluxing with the substituted semicarbazides. The yield of synthesized compounds was appreciable and their physicochemical characteristics are presented in Table 1. The progress of reaction and purity of compounds was confirmed from the consistent spectral data.

Figure 1: Synthetic route for substituted pyrazole carboxamide derivatives.<smiles>[R]c1ccc(C(=O)C=Cc2ccc(C(=O)O)o2)cc1</smiles>

$4 \mathrm{hrs}$

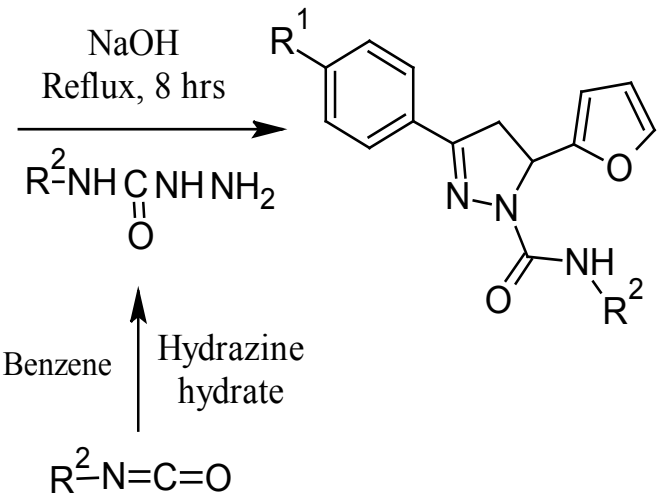

Table 1: Physiochemical properties of synthesized pyrazole carboxamide derivatives.

\begin{tabular}{|l|l|l|l|l|l|l|}
\hline Compound & $\mathbf{R}^{\mathbf{1}}$ & $\mathbf{R}^{\mathbf{2}}$ & Mol. formula & M. Pt. $\left({ }^{\circ} \mathbf{C}\right)$ & $\mathbf{R}_{\mathbf{f}}^{*}$ & \% yield \\
\hline 1 & $-\mathrm{CH}_{3}$ & $-\mathrm{C}_{6} \mathrm{H}_{5}$ & $\mathrm{C}_{18} \mathrm{H}_{21} \mathrm{~N}_{3} \mathrm{O}_{2}$ & $255-257$ & 0.70 & 48 \\
\hline 2 & $-\mathrm{OCH}_{3}$ & $-\mathrm{C}_{6} \mathrm{H}_{5}$ & $\mathrm{C}_{17} \mathrm{H}_{18} \mathrm{FN}_{3} \mathrm{O}_{2}$ & $220-225$ & 0.76 & 54 \\
\hline 3 & $-\mathrm{OC}_{2} \mathrm{H}_{5}$ & $-\mathrm{C}_{6} \mathrm{H}_{5}$ & $\mathrm{C}_{17} \mathrm{H}_{18} \mathrm{ClN}_{3} \mathrm{H}_{8}$ & $240-242$ & 0.30 & 45 \\
\hline 4 & $-\mathrm{Cl}$ & $-\mathrm{C}_{6} \mathrm{H}_{5}$ & $\mathrm{C}_{17} \mathrm{H}_{18} \mathrm{~N}_{2} \mathrm{O}_{4}$ & $180-190$ & 0.47 & 65 \\
\hline 5 & $-\mathrm{Br}$ & $-\mathrm{C}_{6} \mathrm{H}_{5}$ & $\mathrm{C}_{17} \mathrm{H}_{18} \mathrm{BrN}_{3} \mathrm{O}_{4}$ & $200-202$ & 0.51 & 57 \\
\hline 6 & $-\mathrm{F}$ & $-\mathrm{C}_{6} \mathrm{H}_{5}$ & $\mathrm{C}_{17} \mathrm{H}_{21} \mathrm{~N}_{3} \mathrm{O}_{2}$ & $230-232$ & 0.57 & 40 \\
\hline 7 & $-\mathrm{NO}_{2}$ & $-\mathrm{C}_{6} \mathrm{H}_{5}$ & $\mathrm{C}_{19} \mathrm{H}_{23} \mathrm{~N}_{3} \mathrm{O}_{2}$ & $238-240$ & 0.80 & 55 \\
\hline 8 & $-\mathrm{CH}_{3}$ & $-\mathrm{CH}\left(\mathrm{CH}_{3}\right)_{2}$ & $\mathrm{C}_{22} \mathrm{H}_{21} \mathrm{~N}_{3} \mathrm{O}_{3}$ & $210-212$ & 0.66 & 57 \\
\hline
\end{tabular}


Pyrazole derivatives as anti-alzheimer's agents

\begin{tabular}{|l|l|l|l|l|l|l|}
\hline \hline 9 & $-\mathrm{OCH}_{3}$ & $-\mathrm{CH}\left(\mathrm{CH}_{3}\right)_{2}$ & $\mathrm{C}_{21} \mathrm{H}_{19} \mathrm{~N}_{3} \mathrm{O}_{3}$ & $273-275$ & 0.23 & 49 \\
\hline 10 & $-\mathrm{OC}_{2} \mathrm{H}_{5}$ & $-\mathrm{CH}\left(\mathrm{CH}_{3}\right)_{2}$ & $\mathrm{C}_{21} \mathrm{H}_{19} \mathrm{~N}_{3} \mathrm{O}_{2}$ & $255-257$ & 0.67 & 45 \\
\hline 11 & $-\mathrm{Cl}$ & $-\mathrm{CH}\left(\mathrm{CH}_{3}\right)_{2}$ & $\mathrm{C}_{20} \mathrm{H}_{16} \mathrm{FN}_{3} \mathrm{O}_{2}$ & $300-302$ & 0.60 & 58 \\
\hline 12 & $-\mathrm{F}$ & $-\mathrm{CH}\left(\mathrm{CH}_{3}\right)_{2}$ & $\mathrm{C}_{20} \mathrm{H}_{16} \mathrm{ClN}_{3} \mathrm{O}_{3}$ & $275-277$ & 0.38 & 60 \\
\hline 13 & $-\mathrm{NO}_{2}$ & $-\mathrm{CH}\left(\mathrm{CH}_{3}\right)_{2}$ & $\mathrm{C}_{20} \mathrm{H}_{16} \mathrm{BrN}_{3} \mathrm{O}_{3}$ & $285-287$ & 0.83 & 76 \\
\hline 14 & $-\mathrm{Br}$ & $-\mathrm{CH}\left(\mathrm{CH}_{3}\right)_{2}$ & $\mathrm{C}_{20} \mathrm{H}_{16} \mathrm{~N}_{4} \mathrm{O}_{4}$ & $270-272$ & 0.22 & 60 \\
\hline 15 & $-\mathrm{CH}_{3}$ & $-\mathrm{CH}_{2} \mathrm{C}_{6} \mathrm{H}_{5}$ & $\mathrm{C}_{21} \mathrm{H}_{18} \mathrm{~N}_{4} \mathrm{O}_{4}$ & $270-272$ & 0.70 & 60 \\
\hline 16 & $-\mathrm{OCH}_{3}$ & $-\mathrm{CH}_{2} \mathrm{C}_{6} \mathrm{H}_{5}$ & $\mathrm{C}_{22} \mathrm{H}_{21} \mathrm{~N}_{3} \mathrm{O}_{4}$ & $250-252$ & 0.64 & 55 \\
\hline 17 & $-\mathrm{OC}_{2} \mathrm{H}_{5}$ & $-\mathrm{CH}_{2} \mathrm{C}_{6} \mathrm{H}_{5}$ & $\mathrm{C}_{22} \mathrm{H}_{22} \mathrm{~N}_{3} \mathrm{O}_{2}$ & $255-257$ & 0.43 & 65 \\
\hline 18 & $-\mathrm{Cl}$ & $-\mathrm{CH}_{2} \mathrm{C}_{6} \mathrm{H}_{5}$ & $\mathrm{C}_{22} \mathrm{H}_{23} \mathrm{~N}_{3} \mathrm{O}_{3}$ & $258-260$ & 0.69 & 53 \\
\hline 19 & $-\mathrm{Br}$ & $-\mathrm{CH}_{2} \mathrm{C}_{6} \mathrm{H}_{5}$ & $\mathrm{C}_{21} \mathrm{H}_{18} \mathrm{~N}_{3} \mathrm{O}_{2}$ & $260-262$ & 0.75 & 48 \\
\hline 20 & $-\mathrm{NO}$ & $-\mathrm{CH}_{2} \mathrm{C}_{6} \mathrm{H}_{5}$ & $\mathrm{C}_{21} \mathrm{H}_{18} \mathrm{FN}_{3} \mathrm{O}_{2}$ & $260-262$ & 0.46 & 59 \\
\hline 21 & $-\mathrm{F}$ & $-\mathrm{CH}_{2} \mathrm{C}_{6} \mathrm{H}_{5}$ & $\mathrm{C}_{21} \mathrm{H}_{18} \mathrm{BrN}_{3} \mathrm{O}_{2}$ & $280-282$ & 0.67 & 66 \\
\hline
\end{tabular}

*TLC mobile phase: $\mathrm{n}$-hexane: ethyl acetate (7:3)

The ${ }^{1} \mathrm{H}-\mathrm{NMR}$ spectra of compounds showed the singlet signal equivalent to one proton of the -NHCO group around $\delta$ $10 \mathrm{ppm}$, thus confirming the formation of carboxamide bond in the synthesized molecules. The signal for the NH proton was observed at $\delta 2.5 \mathrm{ppm}$ which confirmed the presence of pyrazoline ring by the reaction of chalcones derivatives and substituted semi-carbazides. The ${ }^{1} \mathrm{H}-\mathrm{NMR}$ spectra of compounds exhibited the presence of two unequivalent protons to that of a methylene group $\left(\mathrm{H}_{\mathrm{A}} / \mathrm{H}_{\mathrm{B}}\right)$ at $\delta 3.00-3.40 \mathrm{ppm}$ and $3.72-3.80 \mathrm{ppm}$ coupled with each other and in turn with the vicinal methine proton $(\mathrm{H}-5)$ at $\delta 6.38-6.5 \mathrm{ppm}$. A doublet signal was observed at $\delta$ $6.30-6.45 \mathrm{ppm}$ indicating the presence of furan-2-yl ring in the synthesized compounds. Multiplet signal in the range of $\delta 6.5$ $7.5 \mathrm{ppm}$ showed the substitution at 4-postion of the phenyl ring. The protons belonging to the aromatic ring and the other aliphatic groups were observed with the expected chemical shift and integral values. The IR spectra of the compounds revealed absorption bands in the regions $1080-1300 \mathrm{~cm}^{-1}$ corresponding to $\mathrm{C}=\mathrm{N}$ stretching bands formed due to ring closure indicating the presence of pyrazoline ring in the synthesized compounds. $\mathrm{C}=\mathrm{O}$ stretching $\left(1820-1670 \mathrm{~cm}^{-1}\right)$, N-H stretching $\left(3500-3100 \mathrm{~cm}^{-1}\right)$ and $\mathrm{N}-\mathrm{H}$ bending $\left(1640-1550 \mathrm{~cm}^{-1}\right)$ frequencies revealed the formation of carboxamide bond in the synthesized molecules.

\section{Docking studies}

Docking studies were performed to evaluate the affinity and binding interactions of synthesized molecules in active site of MAO-B (PDB entry: 2V61) and AChE (PDB entry: 1EVE) using Auto Dock vina and Auto Dock Tools. The docking protocol was evaluated by docking of the co-crystallized ligand into the active site of $2 \mathrm{~V} 61$ and the resulting binding pose was compared with that of co-crystallized ligand. The ligand had a similar binding pattern and superposition to that of co-crystallized ligand, thus validating the docking protocol. All the designed compounds were docked in the active site of MAO-B protein and AChE. Amongst all the molecules, 4,8,11,17 and 20 had appreciable binding to the binding site as determined by analyzing the binding free energy $(\Delta G)$ and binding mode of the selected best docked poses (Table 2). On the basis of their lowest binding free energy and docking interaction in the binding site, compounds 4,8,11,17 and 20 were further analyzed in details by PyMOL. The overlay of the selected compounds with the PDB ligand 2V61 showed that the selected compounds had the similar binding pattern in the binding site of the protein as that of the co-crystallized ligand of 2V61 and thus has similar type of binding interactions (Figure 2 and 3). The overlay of the selected compounds with the PDB ligand 2V61 helped us in predicting that the synthesized pyrazole derivatives could act as strong MAO-B inhibitors.

Table 2: Docking score and molecular properties of best docked poses of the synthesized compounds.

\begin{tabular}{|c|c|c|c|c|c|c|}
\hline Compound & $\begin{array}{c}\Delta G(\mathrm{kcal} / \mathrm{mol}) \\
\text { for MAO-B }\end{array}$ & $\begin{array}{l}\Delta G(\mathrm{kcal} / \mathrm{mol}) \\
\quad \text { for AchE }\end{array}$ & Mol. Wt. & $\log P^{*}$ & HBA* & HBD* \\
\hline 1 & -7.9 & -8.5 & 311 & 4.38 & 2 & 1 \\
\hline 2 & -7.6 & -8.2 & 315 & 3.71 & 3 & 1 \\
\hline 3 & -7.0 & -8.1 & 331 & 4.07 & 3 & 1 \\
\hline 4 & -8.1 & -9.9 & 342 & 4.47 & 2 & 1 \\
\hline 5 & -6.9 & -8.8 & 376 & 4.64 & 2 & 1 \\
\hline 6 & -8.0 & -8.9 & 327 & 4.01 & 2 & 1 \\
\hline 7 & -6.3 & -9.3 & 341 & 3.81 & 4 & 1 \\
\hline 8 & -8.8 & -10.4 & 375 & 3.14 & 2 & 1 \\
\hline 9 & -7.2 & -7.6 & 361 & 2.47 & 3 & 1 \\
\hline 10 & -7.8 & -9.3 & 345 & 2.82 & 3 & 1 \\
\hline 11 & -8.5 & -9.4 & 349 & 3.23 & 2 & 1 \\
\hline 12 & -7.1 & -9.0 & 365 & 2.77 & 2 & 1 \\
\hline
\end{tabular}


Pyrazole derivatives as anti-alzheimer's agents

\begin{tabular}{|l|l|l|l|l|l|l|}
\hline 13 & -8.1 & -8.1 & 410 & 2.56 & 4 & 1 \\
\hline 14 & -8.4 & -9.8 & 376 & 3.39 & 2 & 2 \\
\hline 15 & -7.9 & -10.4 & 390 & 4.09 & 3 & 1 \\
\hline 16 & -7.0 & -10.1 & 359 & 3.42 & 3 & 1 \\
\hline 17 & -8.5 & -9.9 & 375 & 3.77 & 2 & 1 \\
\hline 18 & -7.2 & -8.9 & 389 & 4.18 & 2 & 1 \\
\hline 19 & -7.6 & -9.5 & 379 & 4.34 & 3 & 1 \\
\hline 20 & -8.1 & -9.2 & 363 & 3.52 & 2 & 1 \\
\hline
\end{tabular}

* $\log$ P, HBA, HBD, Mol. wt. were calculated by Marvin tools of Marvin Sketch v 5.5.

(a)

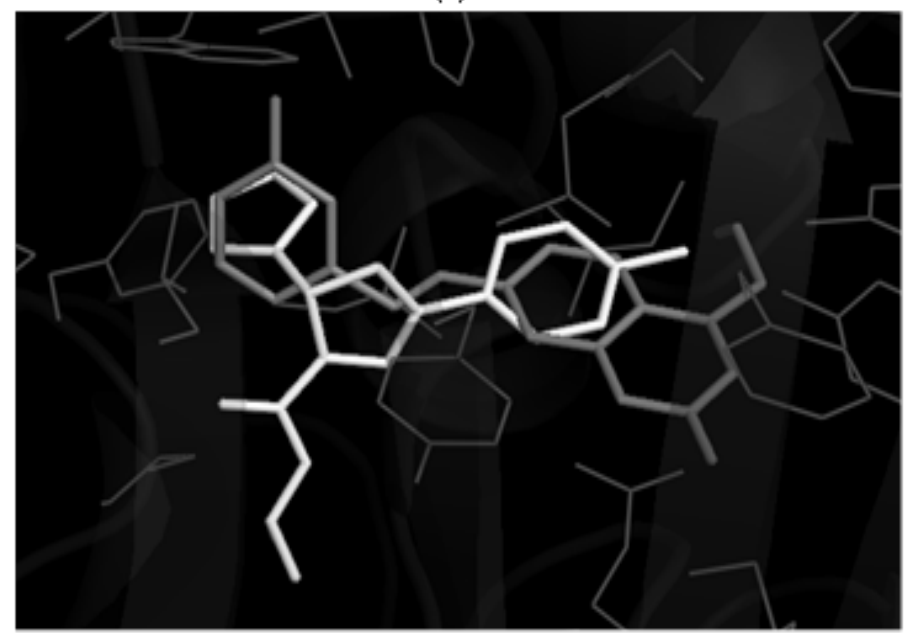

(b)

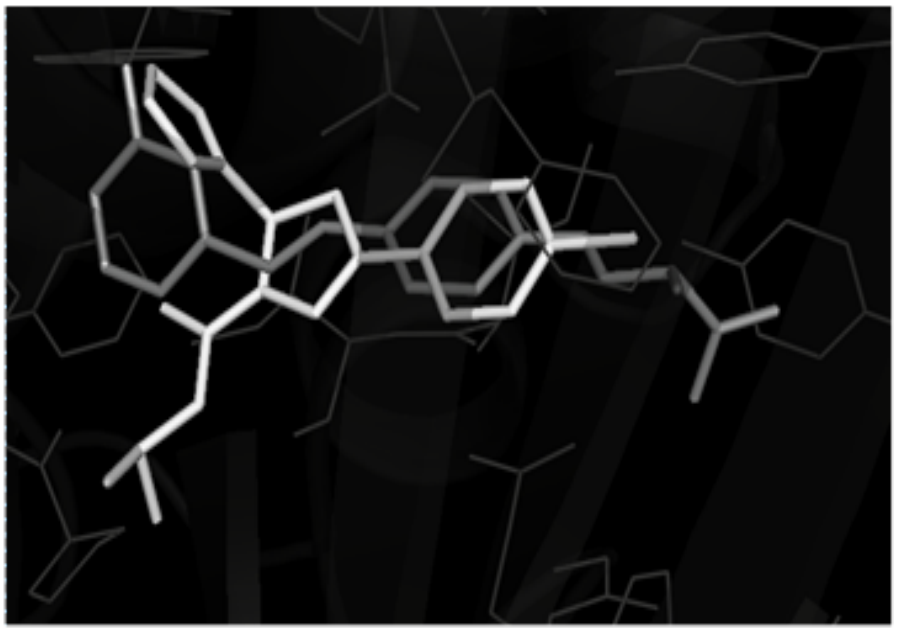

Figure 2: Docked pose for compounds 8 (a) and 11 (b) and PDB ligand of 2 V61 in the binding site of MAO-B protein.

(a)

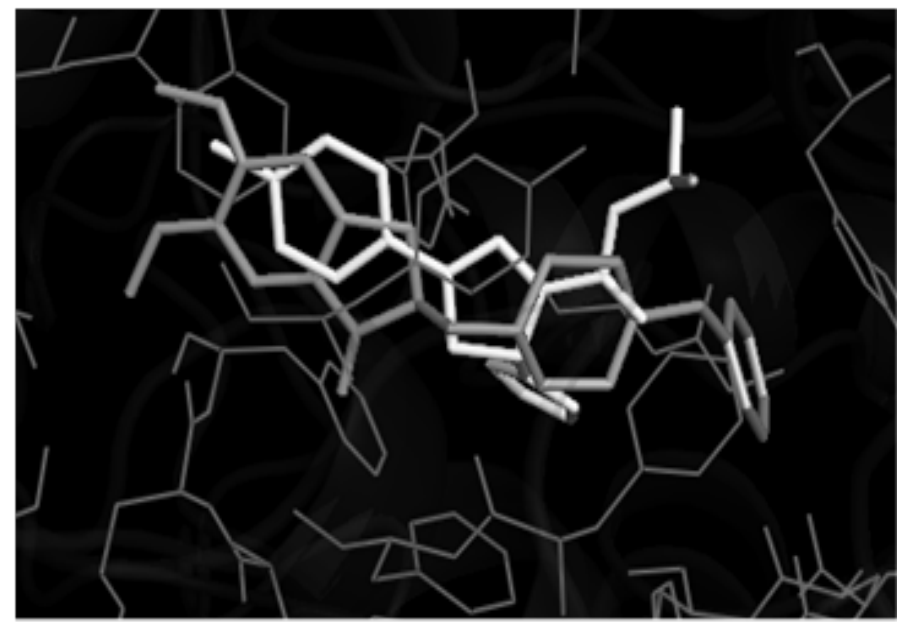

(b)

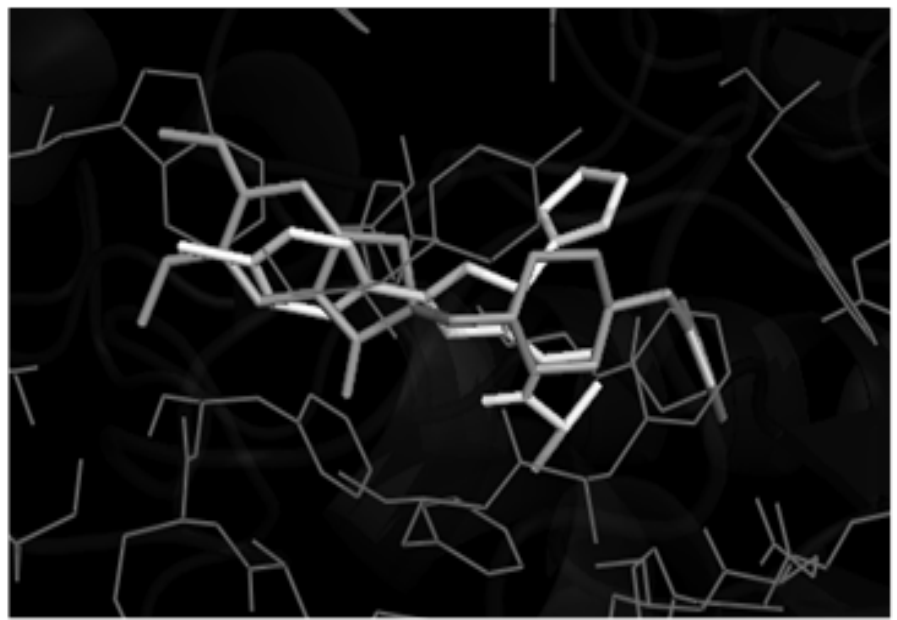

Figure 3: Docked pose for compounds 8 (a) and 11 (b) and PDB ligand of 1EVE (donepezil) in the binding site of AchE protein.

\section{Evaluation of anti-AD activity}

Based on the results of docking studies compounds 4, 8,11, 17, and 20 were evaluated in vivo in rats for anti-AD using an EPM test taking donepezil as standard anti-AD drug. The time taken by the animal to enter one of the closed arms (transfer latency (TL), considered as day 1) was recorded with the help of a stop watch. The mouse was left in the enclosed arm for 10-15s and returned to its home cage. On day 8, i.e., second day of the EPM exposure, the same procedure was repeated and TL was recorded. The results of anti-AD activity measured as TL on day 1 and day 2 are presented in Table 3 . The effect of the orally given selected compounds on changes in TL was analyzed by one-way ANOVA. Statistical analysis showed significant differences in TL among treatment groups $(\mathrm{p}<0.001)$. The results of anti-AD activity indicated that compounds 8 and 11 were found to be highly active with compound 8 showing better potency than compound 11. Compound 8 was also found to be more potent than the standard drug do- 
nepezil.

Table 3: Effect of orally administered compounds on cognition enhancing and scopolamine-induced amnesia.

\begin{tabular}{|l|c|c|}
\hline \multirow{2}{*}{ Treatment } & \multicolumn{2}{|c|}{ Transfer latency (s) } \\
\cline { 2 - 3 } & Day 1 & Day 2 \\
\hline $\mathbf{4}$ & $57.76 \pm 2.89$ & $46.92 \pm 4.17^{* *}$ \\
\hline $\mathbf{8}$ & $33.52 \pm 4.05$ & $24.34 \pm 3.17^{* *}$ \\
\hline $\mathbf{1 1}$ & $39.24 \pm 3.46$ & $27.31 \pm 2.50^{* *}$ \\
\hline $\mathbf{1 7}$ & $64.28 \pm 4.21$ & $53.08 \pm 3.57^{* *}$ \\
\hline $\mathbf{2 0}$ & $64.75 \pm 2.18$ & $48.19 \pm 4.45^{* *}$ \\
\hline Scopolamine alone & $80.73 \pm 1.54$ & $94.54 \pm 1.27^{*}$ \\
\hline Vehicle only (control) & $67.41 \pm 3.43$ & $57.53 \pm 3.42$ \\
\hline Donepezil (Standard drug) & $41.51 \pm 1.45$ & $25.31 \pm 1.24^{* *}$ \\
\hline
\end{tabular}

Data are expressed as mean \pm SEM $(n=6)$. Data are statistically analyzed by one-way ANOVA; *Scopolamine treated groups are significantly different from control group $\mathrm{p}<0.001^{* *}$ significantly different from scopolamine treated group $\mathrm{p}<0.001$.

\section{Estimation of AChE inhibitory activity}

The effects of selected compounds for AChE activity in brain are presented in Figure 4. The results showed significantly different AChE activity between the groups as determined by ANOVA. All the compounds significantly decreased the AChE activity in brain as compared to control. These results suggest that pyrazole derivatives due to their anti-AChE activity enhance cholinergic neurotransmission in brain and thus enhance learning and memory functions.

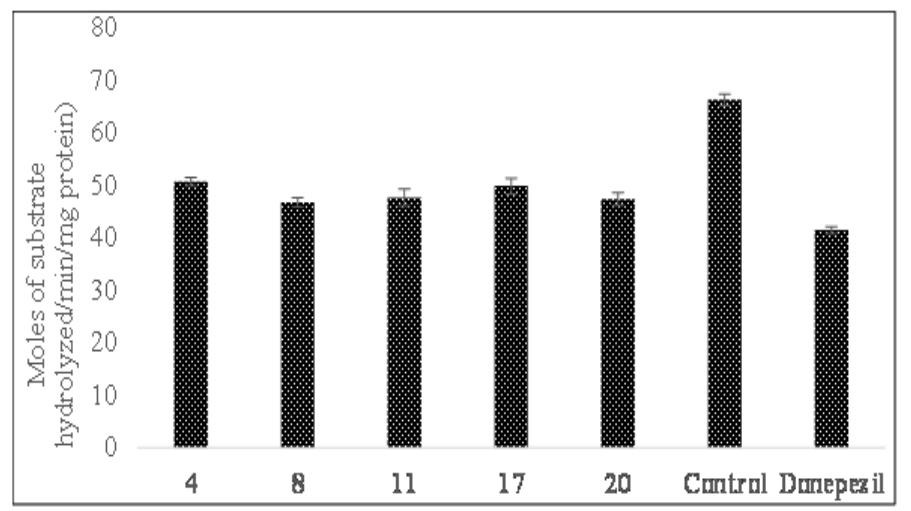

Figure 4: Effect of orally administered compounds on AChE activity in brain.

\section{Conclusion}

The present research work involved the design, synthesis and evaluation of some novel pyrazole derivatives considered to have dual inhibitors of MAO-B and AChE as anti-AD agents. In silico studies were performed for the synthesized molecules and compounds 4,8,11,17, and 20 were selected for in vivo anti-AD. Molecules were evaluated for anti-AD activity by EPM test using donepezil as standard anti-AD drug. Amongst the synthesized substituted pyrazole derivatives, compounds 8 and 11 showed higher anti-AD activity. Compound 8 was found to be more potent than standard drug donepezil. The experimental results were found to be in concordance with that of the in silico results for MAO-B activity and all the synthesized molecules possessed drug like properties as devised by Lipinski rule of five. These new designed molecules could act as initial hit molecules for the design of effective and orally bioavailable dual inhibitors of MAO-B and AChE for the potential treatment of AD.

Acknowledgements: The authors are thankful to the Management, JCD Vidyapeeth, Sirsa (Haryana) for their support and encouragement for this research work. 


\section{References}

1. Bartus, R.T., Dean, R.L., Beer, B.et al. The cholinergic hypothesis of geriatric memory dysfunction. (1982) Science 217(4558): 408-414. Pubmed I Crossref

2. Yokel, R.A. The toxicology of aluminum in the brain: a review. (2000) Neurotoxicol 21(5): 813-828.

Pubmed I Others

3. Sinha, S.K., Shrivastava, S.K. Synthesis and evaluation of some new 4-aminopyridine derivatives as a potent antiamnesic and cognition enhancing drugs. (2012) Med Chem Res 21(12): 4395-4402.

Crossref I Others

4. Yamada, N., Hattori, A., Hayashi, T. et al. Improvement of scopolamine-induced memory impairment by Z-ajoene in the water maze in mice. (2004) Pharmacol Biochem Behav 78(4): 787-791.

Pubmed I Crossref

5. Riederer, P., Danielczyk, W., Grunblatt, E. Monoamine oxidase-B inhibition in Alzheimer's disease. (2004) Neurotoxicology 25(1-2): 271-277.

Pubmed I Crossref I Others

6. Cohen, G., Spina, M.B. Deprenyl suppresses the oxidant stress associated with increased dopamine turnover. (1989) Ann Neurol 26(5): 689-690

Pubmed I Crossref I Others

7. Suuronen, T., Kolehmainen, P., Salminen, A. Protective effect of L-deprenyl against apoptosis induced by okadaic acid in cultured neuronal cells. (2000) Bio chem Pharmacol 59(12): 1589-1595.

Pubmed I Crossref । Others

8. Klegeris, A., Mc Geer, P.L. R-(-)-Deprenyl inhibits monocytic THP1 cell neurotoxicity independently of monoamine oxidase inhibition. (2000) ExpNeuroll 66(2): 458-464.

Pubmed I Crossref I Others

9. Parmar, S.S., Pandey, B.R., Dwivedi, C.et al. Anticonvulsant activity and monoamine oxidase inhibitory properties of 1,3,5-trisubstitutedpyrazolines. (1974) J Pharm Sci 63(7): 1152-1155.

Pubmed I Crossref I Others

10. Manna, F., Chimenti, F., Bolasco, A. et al. Inhibition of amine oxidases activity by 1-acetyl-3,5-diphenyl-4,5-dihydro-(1H)-pyrazole derivatives. (2002) Bioorg Med Chem Lett 12(24): 3629-3633.

Pubmed I Crossref I Others
11. Chimenti, F., Maccioni, E., Secci, D. et al. Synthesis, molecular modeling studies, and selective inhibitory activity against monoamine oxidase of 1-thiocarbamoyl-3,5-diaryl-4,5-dihydro- $(1 \mathrm{H})$ - pyrazole derivatives. (2005) J Med Chem 48(23): 7113-7122.

Pubmed I Crossref I Others

12. Yeşilada, A., Gokhan, N., Ozer, I. et al. 5-methyl-8-N-substituted-thiocarbamoyl-7,8-diazabicyclo[4.3.0] non-6-enes: evaluation as BSAO inhibitors and pharmacological activity screening. (1996) Farmaco51(12): 775-781.

Pubmed I Others

13. Gokhan, N., Yesilada, A., Ucar, G. et al. 1-N-substituted thiocarbamoyl-3-phenyl-5-thienyl-2-pyrazolines: synthesis and evaluation as MAO inhibitors. (2003) Arch Pharm 336(3): 362-371.

Pubmed I Crossref I Others

14. Ucar, G., Gokhan, N., Yesilada, A.et al. Interaction of some 1-N-substituted thiocarbamoyl-3-phenyl-5-thienyl-2-pyrazolines with rat liver semicarbazide-sensitive amine oxidase (SSAO). (2005) J Faculty Pharm 25(1): 23-34.

15. Ucar, G., Gokhan, N., Yesilada, A.et al. 1-N-Substituted thiocarbamoyl-3-phenyl-5-thienyl-2-pyrazolines: a novel cholinesterase and selective monoamine oxidase B inhibitors for the treatment of Parkinson's and Alzheimer's diseases. (2005) Neurosci Lett 382(3): 327-331. Pubmed I Crossref I Others

16. Trott, O., OLlson, A.J. AutoDock Vina: improving the speed and accuracy of docking with a new scoring function, efficient optimization and multithreading. (2010) J Comput Chem 31(2): 455-461.

Pubmed I Others

17. Morris, G.M., Huey, R., Lindstrom, W. et al. AutoDock4 and AutoDockTools4: automated docking with selective receptor flexibility. (2009) J Comput Chem 30(16): 2785-2791.

Pubmed I Crossref I Others

18. O’Boyle, N.M., Banck, M., James, C.A.et al. Open Babel: an open chemical toolbox. (2011)J Cheminform 3: 33.

Pubmed I Crossref I Others

19. Ojha, R., Sahu, A.N., Muruganandam, A.V. et al. Asparagus recemosus enhances memory and protects against amnesia in rodent models. (2010) Brain Cogn 74(1): 1-9.

Pubmed I Crossref I Others
Ommega Online Publisher

Journal of Medicinal Chemistry \& Toxicology

Short Title : J Med Chem Toxicol
E-mail: medchemtoxic@ommegaonline.org

website: www.ommegaonline.org 